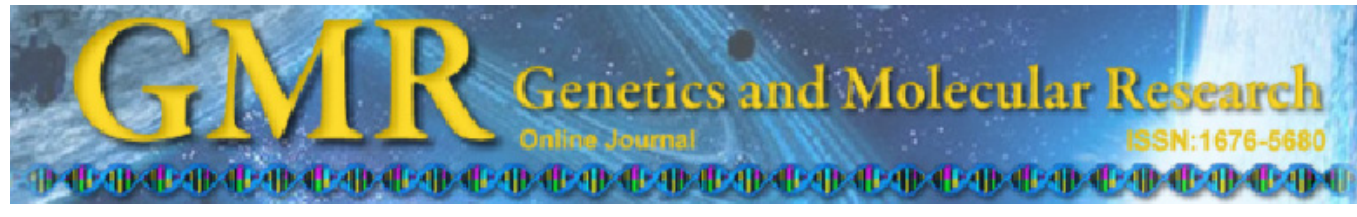

\title{
Genetic characterization of fig tree mutants with molecular markers
}

\author{
M.G.F. Rodrigues ${ }^{1}$, A.B.G. Martins ${ }^{2}$, J.A. Desidério ${ }^{2}$, B.W. Bertoni ${ }^{3}$ and \\ M.C. Alves ${ }^{2}$ \\ ${ }^{1}$ Departamento de Genética, Faculdade de Medicina de Ribeirão Preto, \\ Universidade de São Paulo, Ribeirão Preto, SP, Brasil \\ ${ }^{2}$ Departamento de Produção Vegetal, Faculdade de Ciências Agrárias e Veterinárias, \\ Universidade Estadual Paulista "Júlio de Mesquita Filho", Jaboticabal, SP, Brasil \\ ${ }^{3}$ Departamento de Biotecnologia de Plantas Medicinais, \\ Universidade de Ribeirão Preto, Ribeirão Preto, SP, Brasil \\ Corresponding author: M.G.F. Rodrigues \\ E-mail: gabrielafontanetti@hotmail.com
}

Genet. Mol. Res. 11 (3): 1990-1996 (2012)

Received July 13, 2011

Accepted December 22, 2011

Published August 6, 2012

DOI http://dx.doi.org/10.4238/2012.August.6.3

\begin{abstract}
The fig (Ficus carica L.) is a fruit tree of great world importance and, therefore, the genetic improvement becomes an important field of research for better crops, being necessary to gather information on this species, mainly regarding its genetic variability so that appropriate propagation projects and management are made. The improvement programs of fig trees using conventional procedures in order to obtain new cultivars are rare in many countries, such as Brazil, especially due to the little genetic variability and to the difficulties in obtaining plants from gamete fusion once the wasp Blastophaga psenes, responsible for the natural pollinating, is not found in Brazil. In this way, the mutagenic genetic improvement becomes a solution of it. For this reason, in an experiment conducted earlier, fig plants formed by cuttings treated with gamma ray were selected based on their agronomic characteristics of interest. We determined the genetic variability in these fig tree selections, using RAPD and AFLP molecular markers, comparing them to each other and to the Roxo-de-Valinhos, used as the standard. For the reactions of
\end{abstract}


DNA amplification, 140 RAPD primers and 12 primer combinations for AFLP analysis were used. The selections did not differ genetically between themselves and between them and the Roxo-de-Valinhos cultivar. Techniques that can detect polymorphism between treatments, such as DNA sequencing, must be tested. The phenotypic variation of plants may be due to epigenetic variation, necessitating the use of techniques with methylation-sensitive restriction enzymes.

Key words: Ficus carica; Genetic variability; RAPD; AFLP

\section{INTRODUCTION}

The fig tree (Ficus carica L.) is a fruit tree of great world importance and is grown in more than 400 thousand hectares in the world, having yields of more than 1 million tons (Hortibrasil, 2010).

Figs are among the twenty most important fruits exported by Brazil, and they are ranked number three when it comes to the volume of temperate climate fruits sold, producing a yield of 900 tons a year. Brazil is ranked in tenth place in world yield, where it is responsible for 2\% of it (Instituto de Economia Agrícola, 2008).

However, there are some diseases or pest-related problems, which hinder yields and lower profits, such as nematodes, Cerotelium fici Cast., Botrydiplodia $\mathrm{sp}$, Azochis gripusalis Walk., and Zaprionus indianus Gupta. Research in order to help find solutions for some of the problems mentioned above would mean a great contribution to crop development. Therefore, genetic improvement is an extremely important field of research.

The improvement programs of fig trees using conventional procedures in order to obtain new cultivars are rare in many countries, such as Brazil, especially due to the little genetic variability and to the difficulties in obtaining plants from gamete fusion since the wasp Blastophaga psenes, responsible for natural pollination, is not found in Brazil (Ferreira et al., 2009).

Therefore, mutagenic genetic improvement is very important in crop improvement; gathering information on this species, especially regarding its genetic variability is, therefore, necessary, so that appropriate propagation and management projects are developed.

According to Tulmann Neto et al. (1999), physical (different types of radiation) and chemical mutagenic techniques can be used in vitro or in vivo in plant improvement, increasing the genetic variability and allowing genotypes of interest to be obtained.

The detection of the effect of these mutagenic agents can be obtained in a more precise way by using molecular markers, which are an essential tool for a better and more precise understanding of the variability of the materials studied and a great advance in the development of new cultivars (de Oliveira et al., 1996).

Restriction fragment length polymorphism (RFLP), random amplified polymorphic DNA (RAPD), amplified fragment length polymorphism (AFLP), and microsatellites (SSR) are among the most commonly used DNA molecular markers (Karp et al., 1996; Ferreira and Grattapaglia, 1998; Melo et al., 2001).

Based on the above mentioned points, this research aimed at determining the genetic variability in cuttings of fig tree selections obtained from buds that were irradiated with gamma rays, using RAPD and AFLP molecular markers. 


\section{MATERIAL AND METHODS}

The experiment was carried out at the Agricultural and Veterinary Sciences College, UNESP, Jaboticabal Campus, São Paulo State, in partnership with Universidade de Ribeirão Preto, UNAERP, using cuttings from five fig tree selections obtained in a previous experiment at the Engineering College, UNESP, Ilha Solteira Campus, São Paulo State, in which 450 plants were grown from cuttings irradiated with gamma rays, at a dose of $30 \mathrm{~Gy}$, in the Center of Nuclear Energy in Agriculture (CENA/USP), as described by Santos et al. (1997).

Five plants were selected based on morphological characteristics, which are unique or different from the standard "Roxo-de-Valinhos". These 5 plants were propagated and compared to the Roxo-de-Valinhos cultivar as commercial crops.

The treatments and respective characteristics are listed below:

Roxo-de-Valinhos cultivar - control

Irradiated Plant Selection - 440 (IP - 440): long fruit

Irradiated Plant Selection - 433 (IP - 433): long stalk

Irradiated Plant Selection - 189 (IP - 189): large fruit with small closed ostiole

Irradiated Plant Selection - 214 (IP - 214): large fruit

Irradiated Plant Selection - 301 (IP - 301): long, large fruit

All the observed characteristics were constant at the beginning, where two selections were superior to Roxo-de-Valinhos in regard to the characteristics evaluated (Rodrigues et al., 2009).

Five selections of irradiated plants considered mutants were used in this experiment, where they were compared to each other and to the Roxo-de-Valinhos cultivar, used as the standard control. In order to do that, total genomic DNA was extracted from the vegetal tissues, as described by Lodhi et al. (1994).

DNA and primer concentrations were tested for suitability in DNA amplification reactions, besides the different programs to be performed in the thermocycler. A total of 140 RAPD primers were evaluated; they were obtained from the kits $\mathrm{C}$ and $\mathrm{F}$ of Operon Technologies and from the kit UBC RAPD Primer Synthesis Project Oligonuleotide Set 100/3, obtained from the Nucleic Acids - Proteins Service Unit of the University of British Columbia - UBC (Vancouver, Canada). The AFLP molecular markers were used in order to determine genetic variability according to the adapted protocol of Vos et al. (1995). The characteristics of the oligonucleotides used for AFLP analysis are listed in Table 1.

\begin{tabular}{|c|c|c|}
\hline Combination & Primer $E c o \mathrm{R} 1+\mathrm{A}$ & Primer MseI + T \\
\hline 1 & $E+A G$ & $\mathrm{M}+\mathrm{TA}$ \\
\hline 2 & $\mathrm{E}+\mathrm{ATT}$ & $\mathrm{M}+\mathrm{TA}$ \\
\hline 3 & $\mathrm{E}+\mathrm{ATC}$ & $\mathrm{M}+\mathrm{TTC}$ \\
\hline 4 & $\mathrm{E}+\mathrm{AG}$ & $\mathrm{M}+\mathrm{TAA}$ \\
\hline 5 & $\mathrm{E}+\mathrm{AGT}$ & $\mathrm{M}+\mathrm{TA}$ \\
\hline 6 & $\mathrm{E}+\mathrm{AGA}$ & $\mathrm{M}+\mathrm{TT}$ \\
\hline 7 & $\mathrm{E}+\mathrm{AAT}$ & $\mathrm{M}+\mathrm{TTC}$ \\
\hline 8 & $E+A$ & $\mathrm{M}+\mathrm{TAA}$ \\
\hline 9 & $\mathrm{E}+\mathrm{AGT}$ & $\mathrm{M}+\mathrm{T}$ \\
\hline 10 & $\mathrm{E}+\mathrm{ATC}$ & $\mathrm{M}+\mathrm{TA}$ \\
\hline 11 & $\mathrm{E}+\mathrm{ATT}$ & $\mathrm{M}+\mathrm{TCG}$ \\
\hline 12 & $\mathrm{E}+\mathrm{AAT}$ & $\mathrm{M}+\mathrm{TAA}$ \\
\hline
\end{tabular}




\section{RESULTS AND DISCUSSION}

Of the 140 RAPD primers used for the genetic characterization of the selections and the Roxo-de-Valinhos cultivar, 105 amplified well-defined fragments of 250 to $1500 \mathrm{bp}$. The 105 selected primers yielded 439 fragments, with the number of bands produced per primer ranging from 1 (OPC-06 and OPC-10) to 11 (OPF-10), with an average of 4.2 fragments per primer.

Regarding the number of bands obtained with RAPD analysis, in research on the characterization and identification of pear cultivars and selections, Sawazaki et al. (2002) found 353 amplified DNA fragments using 26 primers, of which 250 bands were polymorphic, with an average of 13.5 bands per primer. In a study of elephant grass, 88 bands were identified using 20 RAPD primers for genetic diversity analysis, with an average of 4.4 bands per primer (Pereira et al., 2008). Furthermore, Silva et al. (2008), by using the RAPD technique in order to characterize rabbiteye blueberry genotypes, 89 markers were formed from 9 primers. In determining the genetic variability of acerola fruit, 37 of 94 primers tested led to clear amplifying results and reproducibility, with a total of 164 amplified markers, and an average of 4 bands per primer (Salla et al., 2002).

Of the 439 fragments obtained here, $100 \%$ were found to be monomorphic bands, i.e., they did not show variation concerning the presence or absence of bands of the same length in base pairs among the individuals studied, leading to the conclusion that none of the 140 primers used detected variation among the fig tree mutants, when compared to each other and to the Roxo-de-Valinhos standard (Figure 1).

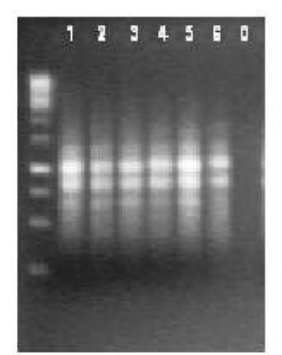

a

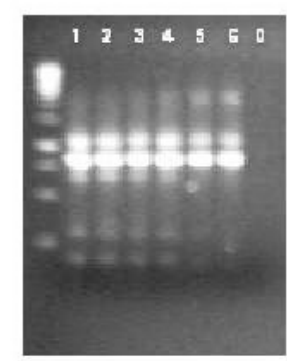

E

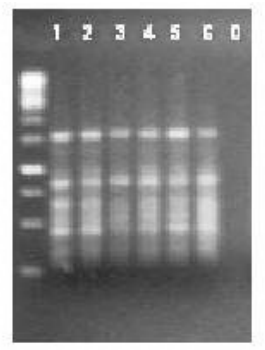

b

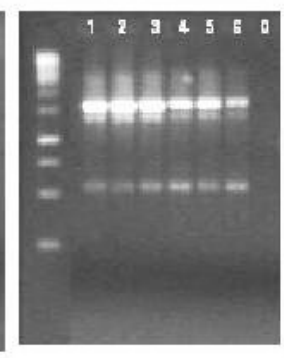

f

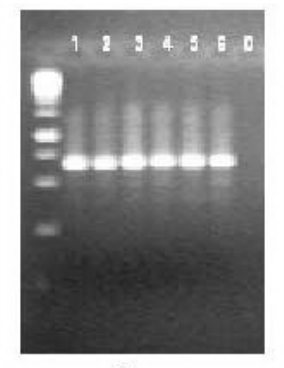

c

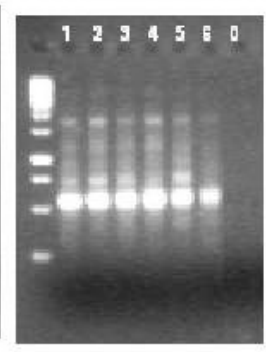

g

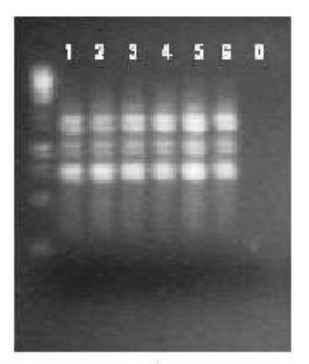

d

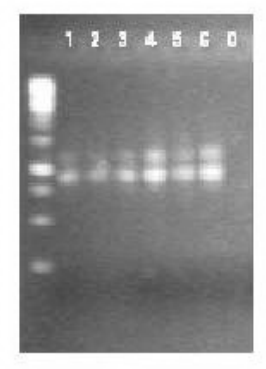

h

Figure 1. Amplification products with RADP markers of mutant sample (Ficus carica L.) cuttings obtained from buds irradiated with gamma rays and from Roxo-de-Valinhos, resolved on agarose gels (1.5\%): a. primer OPC-05; b. primer OPC-06; c. primer OPC-16; d. primer OPF-09; e. primer OPF-13; f. primer UBC-203; g. primer UBC248; h. primer UBC-283. Lanes 1-6 refer to the genotypes [lane 1 = Roxo-de-Valinhos; lane 2 = PI 440; lane $3=$ PI 433; lane $4=$ PI 189; lane $5=$ PI 214; lane $6=$ PI 301]. Lane $0=$ Negative control reaction. 
By using the 12 AFLP primer combinations to evaluate the genetic characterization of mutant cuttings of fig trees (F. carica L.), obtained from buds irradiated with gamma rays, and from Roxo-de-Valinhos, it was possible to obtain 1064 markers, with an average of 88.68 bands by combining the primers evaluated.

In a research on fAFLP markers concerning the characterization of three mume genotypes selected as rootstocks for peach trees, using 24 primer combinations, Wickert et al. (2007) obtained 272 molecular markers, which differed between the three mume genotypes, from a total of 648 markers, thereby yielding an average of 27 bands per primer combination. Santos et al. (2008), analyzing the genetic variability of the umbu fruit tree in a semi-arid area of Brazil, with an average of 14.2 bands per primer combination, obtained 141 and 58 polymorphic and monomorphic bands, respectively, using AFLP and 14 combinations of EcoR1/Mse1 primers (IC). A study of genetic diversity among sweet orange and Murcott tangor hybrids showed that of the 64 oligonucleotide primers used for fAFLP analysis, only 59 led to amplification results considered to provide enough resolution, originating 416 bands (Bastianel et al., 2006). Santos et al. (2001), using only 3 AFLP primer combinations, obtained 437 bands, with an average of 145.6 bands per combination in research on clone varieties of cacao, which shows that the number of bands observed with the AFLP technique depends on the material and on the combination of the primers used, as well as when the RAPD technique is used.

Of the 1064 fragments produced in this experiment, only one polymorphic band was observed, i.e., only one band showed variation regarding the presence or absence of the same base pair length among the individuals studied. This single polymorphic band was obtained from the combination of 5 primers, and polymorphism occurred between individual 3 and the others, as can be observed in Figure 2, which shows the polyacrylamide gels with all the combinations.
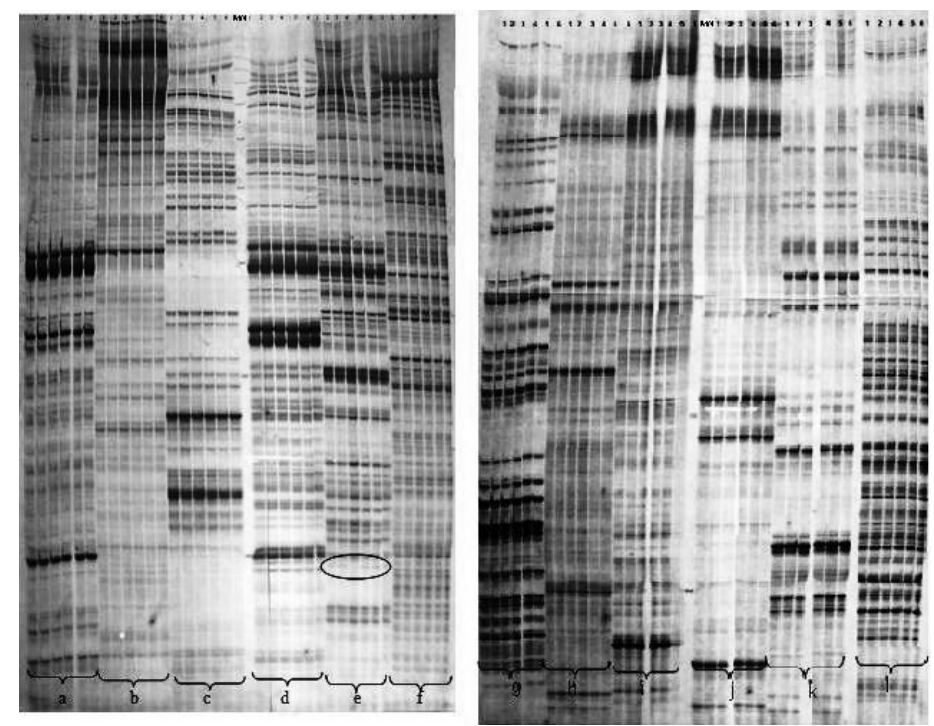

Figure 2. Amplification products with AFLP markers of mutant sample (Ficus carica L.) cuttings obtained from buds irradiated with gamma rays and from the Roxo-de-Valinhos, resolved on polyacrylamide gels: a. combination $1 ; \mathbf{b}$. combination 2; c. combination 3; d. combination 4; e. combination 5; f. combination 6; g. combination 7; h. combination 8; i. combination 9 ; j. combination 10 ; k. combination 11 ; l. combination 12 . Lanes $1-6$ refer to the genotypes [lane $1=$ Roxode-Valinhos; lane 2 = PI 440; lane 3=PI 433; lane 4=PI 189; lane 5 = PI 214; lane 6=PI 301]. MW = Molecular weight. 
Regarding the number of polymorphic bands, a study on genetic dissimilarity in oat mutants generated by irradiation with gamma rays identified a total of 880 markers, of which 195 were polymorphic for 18 ISSR primers, resulting in an average of 48.9 markers and a total of 10.8 polymorphic markers (Souza et al., 2005). These results agree with those obtained in a research on genetic variation and clonal diversity of Psammochloa villosa (Poaceae), which found 122 polymorphic bands for 12 primers evaluated (Li and Ge, 2001).

A study by Malone (2005), aimed at the morphological and molecular characterization of 35 mutants of rice derived from gamma irradiation, using AFLP markers, showed a total of 206 markers from nine combinations of primers, of which 184 were polymorphic between the families studied. These authors demonstrated the great potential of the AFLP technique in detecting genetic variability in these families and rice, and the substantial influence of mutation in creating variability among individuals.

According to these data in the literature, the present results obtained with the molecular markers used showed that there were no significant numbers of polymorphic bands to characterize the study subjects as being genetically different from each other.

\section{CONCLUSIONS}

The fig tree mutants originated from cuttings obtained from buds that were irradiated by gamma rays did not differ genetically between themselves and between them and the Roxode-Valinhos cultivar, using RAPD and AFLP molecular markers. Techniques that can detect polymorphism between treatments, such as DNA sequencing, must be tested. The phenotypic variation of plants may be due to epigenetic variation, necessitating the use of techniques with methylation-sensitive restriction enzymes.

\section{ACKNOWLEDGMENTS}

Research supported by FAPESP in the form of a scholarship.

\section{REFERENCES}

Bastianel M, Oliveira AC, Cristofani M and Machadoi MA (2006). Diversidade genética entre híbridos de laranja-doce e tangor "Murcott" avaliada por fAFLP e RAPD. Pesq. Agropec. Bras.41: 779-784.

de Oliveira AC, Richter T and Bennetzen JL (1996). Regional and racial specificities in sorghum germplasm assessed with DNA markers. Genome 39: 579-587.

Ferreira EA, Pasqual M and Tulmann Neto A (2009). In vitro sensivity of fig plantlets to gamma rays. Scie. Agric. 66: 540-542.

Ferreira ME and Grattapaglia D (1998). Introdução ao Uso de Marcadores Moleculares em Análise Genética. $3^{\mathrm{a}}$ ed. EMBRAPA-CENARGEN, Brasília.

Hortibrasil - Instituto Brasileiro de Qualidade Em Horticultura (2010). O Efeito da Colheita em Diferentes Estágios de Maturação na Qualidade e na Aceitação do Figo pelo Consumidor. Available at [http://www.hortibrasil.org.br/]. Accessed May, 2010.

Instituto de Economia Agrícola - IEA (2008). A Cultura do figo em São Paulo. Available at [http://www.iea.sp.gov.br/]. Accesse April, 2008.

Karp A, Seberg O and Buiatti M (1996). Molecular techniques in the assessment of botanical diversity. Ann. Bot. 78: 143-149.

Li A and Ge S (2001). Genetic variation and clonal diversity of Psammochloa villosa (Poaceae) detected by ISSR markers. Ann. Bot. 87: 585-590. 
Lodhi MA, Ye GN, Weeden NF and Reisch BI (1994). A simple and efficient method for DNA extraction from grapevine cultivars and Vitis species. Plant Mol. Biol. Rep. 12: 6-13.

Malone E (2005). Caracterização Morfológica e Molecular em Mutantes de Arroz (Oryza sativa L.) Quanto à Tolerância a Toxidez por Alumínio. Master's thesis, Universidade Federal de Pelotas, Pelotas.

Melo WMC, Pinho RGV, Santos JB and Ferreira DF (2001). Utilização de caracteres morfoagronômicos e marcadores moleculares para a avaliação da divergência genética entre híbridos de milho. Rev. Ceres 48: 195-207.

Pereira AV, Machado MA, Azevedo ALS, Nascimento CS, et al. (2008). Diversidade genética entre acessos de capimelefante obtida com marcadores moleculares. Rev. Bras. Zootec. 37: 1216-1221.

Rodrigues MGF, Correa LS and Boliani AC (2009). Caracterização de mutantes da cv. Roxo-de-Valinhos e comportamento de cultivares de figueiras. Rev. Bras. Fruticult. 31: 771-777.

Salla MFS, Ruas CF, Ruas PM and Carpentieri-Pípolo V (2002). Uso de marcadores moleculares na análise da variabilidade genética em acerola (Malpighia emarginata D.C.). Rev. Bras. Fruticult. 24: 15-22.

Santos CAF, Rodrigues MA and Zucchi MI (2008). Variabilidade genética do umbuzeiro no Semi-Árido brasileiro, por meio de marcadores AFLP. Pesq. Agropec. Bras. 43: 1037-1043.

Santos PC, Correa LS, Tulmann NETO A and Boliani AC (1997). Sensitividade de estacas de figo a radiação gama. Rev. Bras. Genética 20: 150.

Santos RC, Faleiro FG, Lopes UV, Yamada MM, et al. (2001). Caracterização de variedades clonais de Theobroma cacao L. com base em marcadores RAPD, AFLP e microssatélites. Agrotrópica 13: 79-89.

Sawazaki HE, Barbosa W and Colombo CA (2002). Caracterização e identificação de cultivares e seleções de pereiras através de marcadores RAPD. Rev. Bras. Fruticult. 24: 447-452.

Silva SDA, Antunes LEC, Anthonisen DG, Lemões JS, et al. (2008). Caracterização de genótipos de mirtilo utilizando marcadores moleculares. Rev. Bras. Fruticult. 30: 180-184.

Souza VQ, Pereira AS, Kopp MM, Coimbra JLM, et al. (2005). Dissimilaridade genética em mutantes de aveia tolerantes e sensíveis a ácidos orgânicos. Bragantia 64: 569-575.

Tulmann Neto A, Santos PC and Latado RR (1999). Aspectos Sobre o Melhoramento da Figueira (Ficus carica L.). In: Cultura da Figueira do Plantio a Comercialização (Corrêa LS and Boliani AC, eds.). FAPESP, Ilha Solteira, 25-36.

Vos P, Hogers R, Bleeker M, Reijans M, et al. (1995). AFLP: a new technique for DNA fingerprinting. Nucleic Acids Res. 21: 4407-4414.

Wickert E, Lemos EGM, Pereira FM and Mayer NA (2007). Marcadores fAFLP na caracterização de três genótipos de umezeiro selecionados como porta-enxertos para pessegueiro. Pesq. Agropec. Bras. 42: 1741-1746. 